\title{
UVOD: ŽIVJETI NA KRIVOM PUTU
}

\author{
Milana ČERNELIĆ \\ Filozofski fakultet Sveučilišta u Zagrebu \\ Odsjek za etnologiju i kulturnu antropologiju \\ Ivana Lučića 3, 10000 Zagreb
}

$\mathrm{M}$ onografija, koja se sada nalazi u vašim rukama, nastala je i oblikovana je zaslugom većeg broja ljudi čija su imena zapisana u ovoj knjizi (to se u prvom redu odnosi na istraživače/autore pojedinih priloga i kazivače). Posebno ću izdvojiti samo jednu osobu koja je 1998. godine inicirala etnološka istraživanja kulturne baštine primorskih Bunjevaca. Bio je to profesor Ante Glavičić, u to vrijeme umirovljeni ravnatelj Gradskog muzeja Senj i tajnik Senjskog muzejskog društva, neumorni inicijator brojnih raznorodnih istraživanja na širem senjskom području. ${ }^{1}$

Na temelju rezultata tih početnih preliminarnih istraživanja na području Senjskoga bila i Krivoga Puta, došlo je do inicijative za osmišljavanje prijedloga projekta etnoloških istraživanja šireg područja naseljenoga primorskim Bunjevcima (planinski prostor Velike Kapele i Velebita). Ministarstvo znanosti i tehnologije Republike Hrvatske (danas: Ministarstvo znanosti, obrazovanja i športa) odobrilo je izvođenje projekta pod naslovom Identitet i etnogeneza primorskib Bunjevaca. ${ }^{2}$ Ova monografija predstavlja jedan od rezultata istraživanja u okviru toga projekta. Vremenska i financijska ograničenja nisu nam dopuštala da istraživanjem obuhvatimo širi prostor naseljen primorskim Bunjevcima. Tako je u potpunosti izostavljeno istraživanje na području Krmpota, a istraživanja na području Podgorja tek su započeta. ${ }^{3}$ Sustavna etnološka istraživanja obavljena su i na području Senjskoga bila i Krasna.

Ciljevi projekta su sljedeći: prikupljanje građe o tradicijskoj i suvremenoj kulturi primorskih Bunjevaca, utvrđivanje odrednica njihova identiteta, kao i proširivanje spoznaja o njihovoj etnogenezi na temelju usporedbi kulturnih obilježja ove bunjevačke zajednice s ostalim granama Bunjevaca (u Bačkoj u Vojvodini i Mađarskoj, u Lici i Gorskom kotaru te na širem prostoru njihove matične pradomovine koja zahvaća jadransko-dinarski granični pojas). ${ }^{4} \mathrm{Rad}$ na ovome projektu već je dao vidljive rezultate u spoznajama o brojnim aspektima tradicijske kulturne baštine primorskih Bunjevaca, kao i o njihovu etnoregionalnom identitetu. Nije manje značajan ni doprinos u istraživanju bunjevačke etnogeneze, iako ta istraživanja iziskuju kontinuitet. ${ }^{5}$ Rezultati dobiveni radom na ovom projektu mogu se smatrati jednom fazom u istraživanju ove problematike koju je potrebno nadalje nadograđivati jer je istraživanjem nužno obuhvatiti sve bunjevačke grane i uzimati u obzir širi prostorni kontekst kroz dulje vrijeme. ${ }^{6}$

O tim početnim istraživanjima vidi više u: Černelić, Milana (2000): Prvi rezultati istraživanja tradicijske kulture primorskih Bunjevaca, Senjski zbornik, 27:325-328, Senj.

2 Predviđeno trajanje projekta bilo je tri godine. Nakon toga, rad na projektu produljen je do kraja 2006. godine.

3 Istraživanja na području Podgorja, nastavljaju se u okviru novoga projekta "Identitet i etnokulturno oblikovanje Bunjevaca”.

4 Podrobnije o radu na Projektu vidi u: Černelić, Milana (2003): Istraživanje tradicijske baštine, identiteta i etnogeneze primorskih Bunjevaca. Senjski zbornik, 30:407-408, Senj; Ibid. (2006): Bunjevačke studije. Sveučilište u Zagrebu, Filozofski fakultet, Odsjek za etnologiju i kulturnu antropologiju, FF-press:23-28.

5 Dio rezultata dosadašnjih istraživanja objavljeni su u brojnim prilozima u časopisu Senjski zbornik 30 (2003), 31 (2004), 32 (2005) i 33 (2006), u radovima sljedećih autora: Marijana Belaj, Danijela Birt, Milana Černelić, Jasmina Jurković, Petra Kelemen, Marija Kulišić, Sanja Lončar, Nevena Škrbić Alempijević, Ivana Radovani, Marijeta Rajković, Tihana Rubić, Aleksandra Vlatković, Ivana Vuković, i u časopisu Studia etnologica Croatica (Belaj 2004; Šarić Žic 2004, Černelić 2005; Rajković-Jurković, 2006).

6 Takvim istraživanjima bavim se čitav svoj radni vijek, a u okviru novoga projekta, nastavljam rad sa suradnicima na daljnjem učvršćivanju i proširivanju dosad stečenih spoznaja. 
Zašto baš znanstvena monografija o Krivome Putu? Istražujući na širem području primorskih Bunjevaca, stjecajem okolnosti često smo skretali na „krivi put“. Etnolozi se često u svom radu susreću $s$ nedostatkom ljudi koje bi ispitivali o različitim temama iz života nekoga kraja. Dogodilo se da smo se u Krivi Put vraćali češće nego u neka druga područja upravo stoga što smo ondje, zahvaljujući brojnim kazivačima, prikupili mnogo podataka koje je iznova trebalo provjeravati i dopunjavati, što je onda vodilo do uvođenja novih tema, novih kazivača i novih istraživača (sl. 1). U tome nas je ohrabrivala gostoljubivost i dobra volja Krivopućana. Iako je stanovništvo Krivoga Puta u znatnoj mjeri raseljeno, ipak smo se često susretali i s ljudima koji su ondje privremeno boravili, tako da se broj kazivača svakim našim dolaskom povećavao. Slijedom takvoga razvoja događaja skupili smo doista bogatu građu o tradicijskoj baštini ovoga kraja koja zahvaća gotovo sve segmente njihova života. Monografija Krivoga Puta rezultat je toga rada i naše zajedničke odluke da uložimo napore kako bi ona ugledala svjetlo dana. Također, uvidjeli smo da bi isključivo etnološka monografija bila nepotpuna bez povijesnih priloga i priloga o govornim osobinama krivoputskih Bunjevaca. Stoga smo angažirali stručnjake i znanstvenike iz drugih znanstvenih disciplina, povijesti i jezikoslovlja, sa željom da u konačnici interdisciplinarnim pristupom pitanju bunjevačkoga fenomena ovom monografijom otvorimo novu stranicu u istraživanju ove sudbinski zanimljive etničke grupe. Iako smo se prostorno ograničili na područje Krivoga Puta, u pojedinim je povijesnim prilozima razmatrana i šira bunjevačka problematika.

Znanstvena monografija kao forma u pravilu trebala bi imati ujednačen slijed nizanja različitih podataka o ljudima i kraju kojim se bavi. U njezinoj realizaciji sudjeluje više autora kojima nismo željeli previše kruto određivati kako da napišu svoje priloge. Ono čega se svi autori pridržavaju opća su načela znanstvenoga rada, ali im nije ograničena individualnost u pristupu obrađivanoj temi. Nastojali smo u prikazu života i običaja Krivopućana izbjegavati nostalgičarsku intonaciju, s rijetkim iznimkama, zato što je, bez obzira na to što je Krivi Put danas raseljen (mnogi su ga napustili, ali se isto tako mnogi barem povremeno vraćaju), jedan od značajnijih ciljeva ove monografije revitalizacija Krivoga Puta. Zvuči kao utopija? Možda, no to ovisi ponajviše o snazi volje samih (većinom bivših) Krivopućana da učine nešto za dobrobit svojega zavičaja.

Jedan od ciljeva objavljivanja ove monografije jest da naš doprinos istraživanju ovoga bunjevačkog kraja bude tek prvi korak koji će biti poticaj za daljnja istraživanja njihove kulturne baštine i u drugim bunjevačkim područjima, njihova identiteta i etnokulturnog oblikovanja (etnogeneze). Možda će zvučati neskromno, ali smatram da ovakav holistički pristup istraživanju bunjevačkoga fenomena predstavlja značajnu inovaciju u hrvatskoj znanstvenoj praksi. Puno se priča o potrebi interdisciplinarnosti u znanstvenim istraživanjima, ali se u praksi ona rijetko provodi. Ova znanstvena monografija rezultat je naših napora da se i u praksi ostvari jedan takav interdisciplinarni pristup. Mogao bi se on možda proširiti i na neka druga znanstvena područja, ali u okviru skromnih mogućnosti (financijski i istraživački resursi) i ovakva se suradnja etnologa sa suradnicima iz spomenutih znanstvenih područja može smatrati značajnim doprinosom novim, sve izraženijim i poželjnijim znanstvenim trendovima. Nije manje značajno ni sudjelovanje studenata dodiplomskoga i poslijediplomskoga studija etnologije i kulturne antropologije u istraživačkome radu. Svima im je pružena prilika da rezultate svojih istraživanja autorski prezentiraju, odnosno da ne budu samo istraživački servis za prikupljanje podataka. Većina ih je to prihvatila te su mnogi od njih autori pojedinih priloga u Monografiji. Pojedini su im radovi već objavljivani u Senjskom zborniku te su poneki kategorizirani kao izvorni znanstveni radovi. Danas su svi oni diplomirani etnolozi, a poneki su već i zaposleni u struci.

Proširivanjem etnoloških tema i uspostavljanjem suradnje sa znanstvenicima drugih struka, tijekom pripreme Monografije, pokazalo se kako se sve što smo pripremili za objavljivanje ne može zbiti u korice samo jedne knjige. Stoga smo odlučili Monografiju objaviti u dva dijela. Smatrali smo kako bi doista bilo šteta reducirati prikaz postignutih rezultata, a veći dio prikupljene građe samo pohraniti u Projektni arhiv Odsjeka za etnologiju i kulturnu antropologiju, gdje bi do nje put našli samo rijetki znanstveni znatiželjnici. Namjera nam je, uskoro, nakon objavljivanja prvog dijela, objaviti i drugi dio Monografije koja je više-manje već pripremljena. 
Prvi dio Monografije, koji je upravo u vašim rukama, sastoji se od sedam tematskih cjelina. U prvoj se cjelini obrađuju povijesne teme: analiziraju se socioetnički i etnokonfesionalni aspekti bunjevačkoga fenomena koji u ranome novom vijeku (16.-18. stoljeće) konstituiraju Bunjevce kao etničku i subetničku grupu; dinarsko-vlaško naslijeđe, seobe, akulturacije i asimilacije, interkulturalna i transkulturna prožimanja, konfesionalizacija, identiteti i dr. (Marko Šarić); prikazuje se molba istaknutih Bunjevaca caru i kralju Rudolfu II. da im se izda povelja o privilegijama i dodijeli grb kakav su naslikali u tekstu molbe te se analizira simbolika grba Bunjevaca Krmpoćana (Enver Ljubović); opisuje se zemljopisni položaj i daje pregled novije povijesti Krivoga Puta, od sredine 19. stoljeća do danas (Blaženka Ljubović); prezentira se kratka povijest krivoputske crkve Gospe Snježne i krivoputske župe (Mile Bogović). Sljedeća tematska cjelina sastoji se od pregleda migracija Krivopućana u 20. stoljeću, u kojemu se nastoje utvrditi njihovi uzroci, vrste migracija te se promatra današnja povezanost migranata i njihovih potomaka s krivoputskom lokalnom zajednicom (Marijeta Rajković), a prikazana je i migracija skupine Krivopućana u okolicu Virovitice, Rezovačke Krčevine i u Podgorje (Marijeta Rajković i Jasmina Jurković). Zasebnu tematsku cjelinu čini podrobna analiza bitnih značajki krivoputskoga govora (Ankica Čilaš Šimpraga). Naredne četiri tematske cjeline čine prikazi različitih etnoloških tema iz područja materijalne kulture. Njihov se izbor temeljio na specifičnim značajkama načina života primorskih Bunjevaca, a stečene spoznaje ujedno predstavljaju i važan doprinos istraživanju identiteta primorskih Bunjevaca: tradicijsko graditeljstvo Krivoga Puta (Ivana Šarić Žic); tradicijsko gospodarstvo (sezonske migracije, stočarstvo, sjenokoša, zemljoradnja, pčelarstvo, lov) (Marijeta Rajković); tradicijski načini prijevoza i opskrbe vodom (Danijela Birt i Matija Dronjić) te tradicijska trgovina i sajmovi (Tihana Rubić). Dakle, prvi dio Monografije interdisciplinarno obrađuje bunjevački fenomen na primjeru mikroregije Krivi Put na obroncima Velike Kapele u senjskome zaleđu.

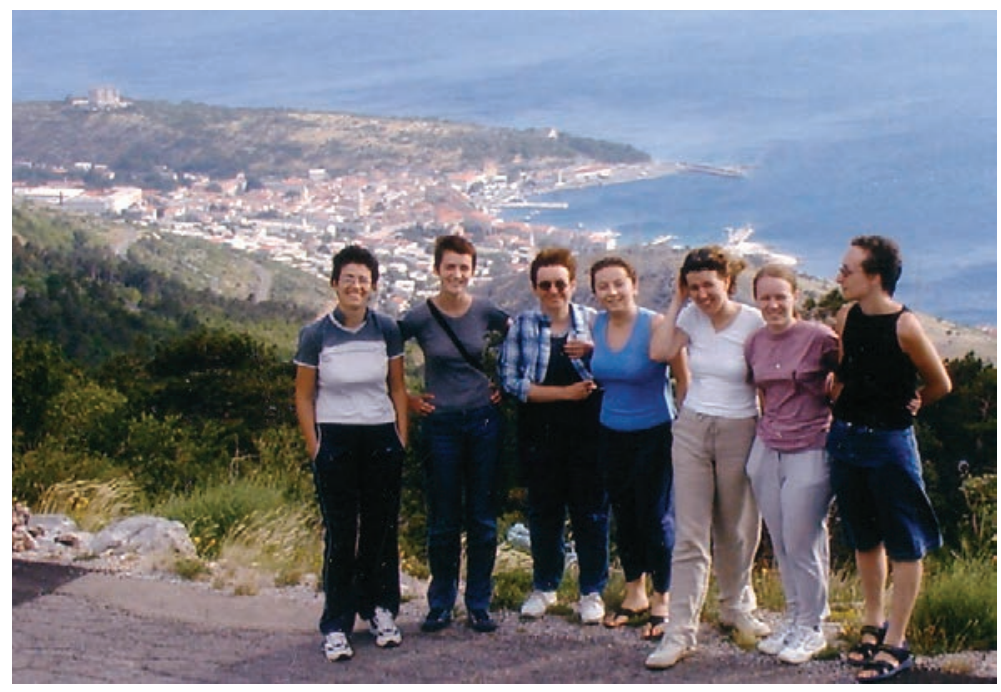

Slika 1: Dio istraživačkoga tima (s lijeva na desno): Danijela Birt, Jasmina Jurkovic, Milana Cernelić, Marijeta Rajković, Nevena Škrbić Alempijevic, Petra Kelemen i Aleksandra Vlatković, na povratku u Senj iz Krivog Puta; snimio Augustin Peric 2003. godine.

U drugom dijelu Monografije namjeravamo objediniti različite etnološke teme, uglavnom iz područja društvene i duhovne kulture, iako sva tri šira etnološka područja, obuhvaćena u oba dijela Monografije, nije uvijek jednostavno odijeliti: pojave iz materijalne kulture često zadiru i u sferu društvene, pa i duhovne kulture, a u životnoj su praksi često isprepletene. U drugom dijelu Monografije bit će zastupljene sljedeće teme: tradicijska prehrana, narodna medicina i zaseban prilog o liječenju zmijskog ujeda, obitelj i obiteljski odnosi, predbračni i izvanbračni život, tradicijsko odijevanje, običaji i vjerovanja (godišnji i svadbeni običaji, sveci zaštitnici, blagdan Majke Božje Snježne, vjerovanja u nadnaravna bića). 
Oblici komuniciranja unutar uže lokalne zajednice, kao i komunikacija s užom i širom okolicom, zadiru u različita područja života Krivopućana. Tematski prilozi različita sadržaja obrađuju razne aspekte života lokalne zajednice. Gotovo svaki prilog u Monografiji (u oba njezina dijela) sadrži neki segment života lokalne zajednice. Selo kao zajednica i skupina sela i zaselaka, koja čine Krivi Put, nalaze se u specifičnoj komunikacijskoj povezanosti kroz različite segmente tradicijske kulture. Seoska društvenost na razini uže (pojedina sela u Krivome Putu) i šire lokalne zajednice Krivopućana (područje Krivoga Puta'), a nerijetko i izvanlokalna komunikacija sa stanovništvom iz bliže i dalje okolice, predstavlja poveznu nit svih zastupljenih tema u oba dijela Monografije. Druga povezna nit je bunjevački identitet, svijest o kojemu se zrcali u svim prilozima u ovoj knjizi. Teme su odabrane prema specifičnim značajkama života primorskih Bunjevaca. Upravo se na pojedinim elementima njihove tradicijske kulture najbolje može pratiti proces izgradnje bunjevačke identifikacije te oni, s jedne strane, predstavljaju objektivne aspekte njihova etniciteta. Bunjevci Krivoga Puta svjesni su svoje bunjevačke pripadnosti i različitosti spram drugih što, s druge strane, predstavlja subjektivni aspekt njihova etniciteta. ${ }^{8}$ Svijest Krivopućana o povezanosti s ostalim bunjevačkim granama nije u svih podjednaka, tako pojedini kazivači ističu zajedničko podrijetlo svih (ili samo nekih) bunjevačkih grana, dok drugi toga nisu svjesni te ističu razlike među njima. ${ }^{9} \mathrm{O}$ različitosti predodžaba Krivopućana o sebi i drugim bunjevačkim granama najbolje svjedoče pojedini primjeri njihovih iskaza:

Milan Prpić Markin iz Veljuna: Bunjevci su od Hercegovine, odozdo, od rijeke Bune. I mi smo Bunjevci. Mi smo odozdo ... prid Turcima se bježalo. A svako prid nožom bježi. Onda su jedni dol po Slavoniji, ima ih po Banatu, Bog zna, svukuda, po Lici, svukud Bunjevaca ... i ovo su ovdje Bunjevci. (Belaj, transkripti 2004, prema: Černelić 2005: 41-42)

Ivan Tomljanović Rokin iz Krivoga Puta (o Bunjevcima u Vojvodini): A to je već drugo, druga narav, druga rasa. A ovo su pravi Bunjevci, Hercegovci. (Rajković, transkripti 2004, prema: Ibid.)

Branko Tomljanović Ropeta iz Senja: To je isto pleme, samo jedno išlo amo, drugo ošlo prema tamo, isti je govor čak, morete vidjeti kako govore Bunjevci iz Tavankuta, baš oko Tavankuta, tamo u Subotici, da je to gotovo isto narječje, isto su ikavci kao i mi, gotovo isto ... a oni računaju, u bivšoj Jugoslaviji da Hrvati, da Bunjevci tamo nisu Hrvati, znate, oni su Bunjevci, to je bilo nekako na nivou Jugoslavije i poslije nisu nekako smatrali te Bunjevce baš za Hrvate, iako su Hrvati, mislim, to je isto pleme, iz istih područja potječu, tako da, ja ne znam, ja kad gledam njih, oni sad imaju nošnju, imaju drugačiju nošnju, imaju drugačija kola, igre, ali govor i ovo po prezimenima, ja mislim da je to mentalitet isti, gotovo isti, po tome bi pozna, a po nečem drugom ne bi. (Lončar, transkripti 2005, prema: Ibid.)

Ivan Vukelić Pop iz Rupe (Alan) tvrdi da Ličani nisu Bunjevci, a o bačkim Bunjevcima, brkajući ih sa Šokcima, kaže sljedeće: Recimo oni su pravi Šokci: Oni su isto ikavci, nisu jekavci i nešto miješaju malo ekavicu. Ali nije to samo zbog utjecaja pravoslavnih običaja jer takvih imaš i u Zagrebu di govore pojedine riječi. I onda oni imaju svoje običaje koje mi nemamo, svoje nošnje, mi ih nemamo ... oni su poznati po šeširima po onim trakama na šešriru znači to je ta šokadija, recimo tako. Što se tiče vrijednosti, oni su dosta vrijedni ljudi, svega su se prihvaćali, dosta su volili zemlju i dosta znaju oko zemlje, volili su i konje, bez konja nisu ništa mogli radit u Slavoniji, bez oranja nema nista. E kakvi su vinari, to ne znam. Izgleda da su dobri, ta područja vina oko Iloka. (Ibid., prema: Ibid.)

Etnološke teme zastupljene u Monografiji odnose se poglavito na tradicijsku kulturnu baštinu Bunjevaca s područja Krivoga Puta, ali se nerijetko prati njihova sudbina i u suvremenom društvenom kontekstu.

Pod područjem Krivoga Puta podrazumijevamo područje koje lokalno stanovništvo prepoznaje kao takvo u razgovorima (Usp. u Uvodu u tradicijsko gospodarstvo, autorice M. Rajković u ovoj monografiji).

8 O objektivnim i subjektivnim aspektima etniciteta vidi više u: Grbić, Jadranka(1994): Identitet, jezik i razvoj, Institut za etnologiju i folkloristiku, Zagreb i Čapo Žmegač, Jasna (1997): Objektivni i subjektivni čimbenici identifikacije sa zajednicom, Etnološka tribina, 20:69-82, Zagreb.

9 O konstrukciji bunjevačkoga identiteta vidi više u: Černelić, Milana (2005): Pristupi istraživanju bunjevačkih identiteta, Studia ethnologica Croatica, 17:25-49, Zagreb. 
Mnoge su teme odabrane upravo iz razloga što bi spoznaje o pojedinim aspektima njihova kulturnoga naslijeđa mogle naći primjenu i u suvremenom životu. Uključivanjem pojedinih elemenata tradicijske kulture u suvremeni život (primjerice kroz revitalizaciju graditeljske baštine, seoski turizam, gastronomsku ponudu, obnavljanje karakterističnih proizvoda, izradu suvenira, obilježavanje karakterističnih blagdanskih okupljanja i sl.) moguće je obogatiti turističku ponudu toga kraja. Pojedini prilozi u Monografiji posebno naglašavaju upravo mogućnosti povezivanja tradicijskoga sa suvremenim nudeći prijedloge kako iskoristiti prirodne resurse i zanemarenu kulturnu baštinu.

Jedan od ciljeva nam je, dakle, bio spoznajama o zanemarenim tradicijskim vrednotama Krivopućana potaknuti stanovništvo toga kraja i njihove potomke na afirmativniji stav prema vlastitome kulturnom naslijeđu, ne bi li ih prepoznavanje njihovih tradicijskih vrijednosti potaklo na inicijativu revitalizacije kraja radi prilagođavanja suvremenim razvojnim trendovima koji su u Europi već uzeli maha, a u nas su još u povojima (uz časne iznimke). Svojim sadržajem Monografija je samo naizgled okrenuta prošlosti. Gotovo svaki od priloga uključio je osvrt na suvremena stanja i promjene koje možemo pratiti kroz određeni vremenski period sve do danas. Također, spoznajama o kulturnome naslijeđu i njegovom valorizacijom, danas možemo učiniti nešto za sutra, kako bismo trajne vrijednosti naše baštine prilagodili duhu vremena u kojemu živimo. Ne istražujemo prošlost zbog nostalgije za starim vremenima, nego zbog pogleda prema budućnosti. Kako kaže predaja o doseljavanju Bunjevaca u taj kraj, Krivopućani su greškom skrenuli prema ovome kraju i otuda potječe naziv Krivi Put. I stoljećima su ondje opstali. Zašto danas ne bi napravili iskorak u budućnost? Na mladim je naraštajima Krivopućana da se potrude to ne zanemariti i da svojemu zavičaju osiguraju budućnost, bez obzira prebivaju li u njegovoj blizini ili negdje daleko od njega.

Prilozi u Monografiji nastali su zahvaljujući brojnim starijim i mlađim Krivopućanima koji su svojom suradnjom omogućili da saznamo sve ono što iznosimo na stranicama koje slijede u ovoj monografiji (nadamo se i u sljedećoj). Upotpunjeno ranije utvrđenim malobrojnim saznanjima i njihovim povezivanjem, sakupili smo sve što se dosad moglo saznati o Krivome Putu. Suradnici na ovoj monografiji potrudili su se da rezultati koje su svojim radom postigli ne ostanu pohranjeni samo kao arhivska građa, za kojom bi tek rijetki istraživači možda jednog dana posegnuli. Stoga smo ustrajali u nakani da taj zajednički trud pretočimo u knjigu koja će, vjerujem, postati primjer kako spoznaje o prošlosti mogu prokrčiti put i prema budućnosti. Nadamo se da će Krivopućani prepoznati ta naša nastojanja i učiniti početne korake u revitalizaciji Krivoga Puta. Istraživanje kulturne baštine toga kraja time neće ostati samo unutar korica ove knjige, već će, nadamo se, uroditi mnogim novim inicijativama. Pozivamo stoga Krivopućane da nastave započeto. Možda bi to mogao biti "pravi put".

Hvala svima koji su pomogli i omogućili objavljivanje ove monografije. 